\title{
M-Learning and Technological Literacy: Analyzing Benefits for Apprenticeship
}

\author{
Carlos Manuel Pacheco Cortés ${ }^{1}$, Adriana Margarita Pacheco Cortés, ${ }^{2, *}$ \\ ${ }^{1}$ Doctoral Student in Education, University of Tartu, Tartu, Estonia \\ ${ }^{2}$ Sistema de Universidad Virtual, University of Guadalajara, Guadalajara, México \\ *Corresponding author: adrianap@cencar.udg.mx
}

Received November 13, 2014; Revised November 18, 2014; Accepted December 01, 2014

\begin{abstract}
The following study consists on comparative literature review conducted by several researchers and instructional designers; for a wide comprehension of Mobile-Learning (abbreviated M-Learning) as an educational platform to provide 'anytime-anywhere' access to interactions and resources on-line, and Technological Literacy (TL), as a potential outcome of Technology Education (the study of Technology). The similarity between MLearning and 'M-Education' might be confusing, in another way, here is explained the difference regarding both. Most of the theory developed on M-Learning was conceived in English, as digital resources of public dominion; however, there is a mention for skills applied by students to use mobile devices, originally conducted in Spanish. The method implemented is deductive/inductive reasoning: Boolean data type. The purpose for this study is to merge it with subsequent investigations, and linking the most outstanding concern with a common dissertation.
\end{abstract}

Keywords: M-Learning, technological literacy, higher education, VLE

Cite This Article: Carlos Manuel Pacheco Cortés, and Adriana Margarita Pacheco Cortés, "M-Learning and Technological Literacy: Analyzing Benefits for Apprenticeship.” American Journal of Educational Research, vol. 2, no. 12 (2014): 1160-1163. doi: 10.12691/education-2-12-5.

\section{Introduction}

Meeting the nature of Mobile Learning, in attempt to route its benefits to Technological Literacy, this study proposes to analyze, as much as possible, the origin from which M-Learning emerged; and to understand the relation concerning several concepts involved with this.

For Sharples, Milrad, Arnedillo-Sánchez \& Vavoula (2007) research into m-learning is 'how mobility of learners, increased by personal and public technology, can contribute to the process of achieving new knowledge, skills and experience'. Interpreting this, students learn anything at any time at any place although they are not at a fixed or predetermined place. Their learning happens, gaining new knowledge, skills or experience, because they have interested about a specific topic and they will be do anything to get information, interactions with other people, get digital resources or materials about their interests. Also, they have different devices to achieve mediations and virtualizations about their reality and contexts, all of these things are part of informal learning. The students will take advantage of the learning opportunities offered by mobile technologies, but with these learning opportunities, will they achieve learning?

According to the Organization for Economic Cooperation and Development (OECD), there are three forms of learning (as a synonym of education - the multidirectional process whereby knowledge, values, customs and behaviors, are transmitted); this statement of forms departs from the theory conceived by Coombs and Ahmed (1974: 8) ${ }^{1}$

1. Formal learning is always organized and structured, and has learning objectives. From the learner's standpoint, it is always intentional: i.e. the learner's explicit aim is to gain develop skills.

2. Informal learning is never organized, has no set objective in terms of learning outcomes and is never intentional from the learner's standpoint. Often referred as learning by experience or just as experience.

3. Mid-way between the first two, non-formal learning is the concept on which there is the least consensus, which is not to say that there is consensus on the other two, simply that the wide variety of approaches in this case makes consensus even more difficult.

\subsection{The Problem}

In this study, there was a lack of a comprehensive framework for implementing m-learning's usability to increase the level of Technological Literacy. In this sense, a process of logical analysis about student's m-learning (i.e. in mobile learning analytics, or MLA). The available theory is inaccurate biased. According to Aljohani \& Davis (2012) MLA focuses on: collection, analysis and reporting of data of learners to learn with mobile devices

\footnotetext{
${ }^{1}$ OECD: Skills beyond schools. Recognition of Non-formal and Informal Learning | Retrieved 19.09.2013 http://www.oecd.org/education/skillsbeyond-school/recognitionofnon-formalandinformallearning-home.htm
} 
using (interactions between learners, available learning resources, materials and others).

What is the relationship between M-Learning and usability?

What is the main benefit of M-Learning for the Apprenticeship?

Would M-Learning increase the level of Technological Literacy among the Society?

\section{Setting the Context}

In 2004, the Executive Council into the University of Guadalajara, approved to create a System of Virtual Campus (in Spanish: Sistema de Universidad Virtual, or SUV) to fit the institution with current necessities of regional society, and in order to improve different formative activities, offering programmes without limits of time/space. Nowadays, the SUV offers formative programmes based on virtual-learning environments (VLE): a baccalaureate, six bachelor-pregraduate, and four postgraduate (3 master, 1 doctoral) degrees. In addition, the SUV gives open courses, providing attention to private sector as much as to the government.

In contrast to that it has been done at the University of Guadalajara, regarding to M-Learning and as a sample of Latin-American research on educational science, at the University of Tartu (as a sample of European research), the studies conducted on M-Learning have been more focused to computational science following the topic "Mobile Web Services" 2. Actually, the context of such studies is not the Republic of Estonia, but the context of countries from which the researchers came from: Germany, China, etc ${ }^{3}$.

\subsection{Review Methods}

The purpose of this review paper is to meet part of the nature concerning the concepts M-Learning and Technological Literacy, and to identify their relation, from a review of literature. The research took place in webbased search engines. The literature search results are introduced in Table 1.

Table 1. Overview of Literature Search Performed in August, 2013

\begin{tabular}{|c|c|c|c|c|}
\hline \multirow[t]{2}{*}{ Concept } & \multicolumn{2}{|c|}{ Source } & Included & Excluded \\
\hline & $\begin{array}{c}\text { REDALYC } \\
\text { Database }\end{array}$ & $\begin{array}{c}\text { GOOGLE } \\
\text { Web } \\
\text { search } \\
\end{array}$ & $\begin{array}{l}\text { Meeting } \\
\text { criteria }\end{array}$ & $\begin{array}{c}\text { Not- } \\
\text { meeting } \\
\text { criteria } \\
\end{array}$ \\
\hline M-Learning & 12 & 7 & 11 & 8 \\
\hline $\begin{array}{c}\text { Technological } \\
\text { Literacy }\end{array}$ & 1 & 3 & 3 & 1 \\
\hline
\end{tabular}

Usability reviews will be conducted to establish the relationship between M.Learning and usability.

\subsubsection{Search Criteria Details}

Web search options: 'language: Spanish, English', 'exact expression: mobile learning, definition' + 'technological literacy, definition' and/or 'm-learning', + 'region: Latin American countries, Europe’

\footnotetext{
${ }^{2}$ http://mc.cs.ut.ee/mcsite/research/mobile-web-services

${ }^{3}$ Mobile Web Services for Collaborative Learning -

http://math.ut.ee/ srirama/publications/wmute_06.pdf
}

Database options: 'URL: www.redalyc.org', 'language: any', 'type: by keywords=m-learning(8) or mlearning(4)', 'discipline: education' REDALYC gives the reviewer search options by article (proceedings), by author, by journal, by discipline, by institution, and by country of Iberian America (Spain, Portugal, Latin America and Caribe).

\section{Technology Education}

Technology Education (TE) is a concept, distinguished from 'educational technology' (Brown and Brown, 2003) and from 'technology in education' (Dieuzeide, 1970). In simple words, TE is the name of a school subject, focused to the students in basic education, or focused to the teachers in higher education.

\section{Educational Technology}

The Educational Technology, in another hand, is the study and ethical practice of facilitating learning and improving performance by creating, using, and managing appropriate technological processes and resources (Januszewski and Molenda, 2008).

\section{Technological Literacy}

Gagel (1995; 1997) in Berrett (2001) suggested that technological literacy is as dynamic as the society we live in and that "as long as humans continue to practice technology, what it takes to be considered technologically literate will change" (1995, p. 296). Moreover, Gagel (1997) suggested that TL implies the ability to use, manage, understand, and assess technology leading to four generalized competencies: (a) accommodate and cope with rapid and continuous technological change, (b) generate creative and innovative solutions for technological problems, (c) act through technological knowledge both effectively and efficiently, and (d) assess technology and its involvement with human life judiciously.

\section{M-Learning}

According to the Standard of Information Security, published by the International Organization for Standardization and by the International Electrotechnical Commission, Mobile leaning is a learning platform that provides learners 'anytime-anywhere' access to educational and university resources. "Learners find themselves empowered by using mobile technology to gain access to the required course materials even when they are disconnected from the network." (ISO/IEC 29140-2; in Alrasheedi and Capretz, 2013; p. 1). At the Monterrey Institute of Technology (MIT, or ITESM for its name in Spanish ${ }^{4}$ ), some studies about Information and Communication Technologies have been made, in attempt to lead alumni to succeed towards a meaningful learning, based on the use of Technology: "since satellite-based models, towards e-learning environments, and more recently, a newer modality for studying was integrated for mobile devices; such modality is known as m-learning (ITESM, 2007a; in Herrera, Lozano and Ramirez, 2008; p. 2).

\footnotetext{
${ }^{4}$ Instituto Tecnológico de Estudios Superiores de Monterrey www.itesm.edu
} 
The lack of 'the single factor of mobility' does not make m-Learning a simple extension of E-learning with an additional feature. The term mobility is not just a feature; it adds several benefits such as self-paced learning, accessibility to learners in remote areas, learning in addition to regular work with immediate application capability etc. (Alrasheedi and Capretz, 2013; p. 3). For instance, Lefoe, Olney, and Wright (2009) identified staff development strategies for using M-Learning technologies in higher education, while discussing how staff members were engaged in using these technologies fox six months prior to introducing them to their students for learning activities within a Faculty of Education; five key strategies to support this learning, were identified: a shared understanding of the theoretical frameworks and philosophies; both an understanding of affordances of the technologies and time to develop skills; participation in authentic tasks; development of a shared language, knowledge and understanding of new pedagogies; and a cycle of reflection. The findings support the notion that a social-constructivist framework provides an exemplary approach for staff development. In another hand, Herrington, Herrington and Mantei (2009) described findings of the project as a whole, and presented principles to inform the design of innovative learning environments employing mobile technologies in higher education learning environments. In a practical sense, design principles can refer to characteristics of a planned learning design: what it should look like; or its procedure: how it should be developed (Van den Akker, 1999). Above all they must be expressed in a way that can inform practice (Wang \& Hannafin, 2005; in Herrington et al, 2009). Moreover, Marcos, Tamez and Lozano (2009; p. 94) propose the m-learning as an alternative way to foster critical analysis through virtual-asynchronic discussion boards (forums), providing students of ITESM with the ability to process information in a more friendly format than the presented by some virtual learning environments, such as 'blackboard'.

The concept of m-learning refers to teaching and learning processes that occur with the support of mobile widgets, involving mobility of human subjects who can be physically/ geographically far from each other and far from formal educational physical spaces, such as classrooms, training / graduation / qualification rooms or workplaces (Zanela, Reinhard, Schlemmer and Barbosa, 2010).

Finally, Zapata (2012) declared: "it could be said that m-learning is actually 'e-learning with less functions' or 'including less-fine features' and more mobility”. While this may seem an obvious or irrelevant conceptualization, m-learning presents new, powerful and radical changes in methodology, due to increased opportunities and areas where to perform activities; but mostly by immersing these in a very powerful social context and accepted by the population as a relationship environment (Zapata, 2012).

\section{M-Education}

Mobile Education, or M-Education, is the name of a project-oriented approach that will use a wireless virtual community to facilitate the learning activities of its participants; through collaboration in a distributed environment (Farooq, Schafer, Rosson, and Carrol, 2002; p. 7). The objective of the m-Education movement is to increase the level of learning and the access to learning through the use of mobile. It is oriented to basic literacy, language skills, vocational training, or any other type of remote based learning.

\section{Learning Analytics}

The 1st International Conference on Learning Analytics and Knowledge (2011) defined Learning Analytics (LA) as the measurement, collection, analysis and reporting of data about learners and their contexts, for purposes of understanding and optimizing learning and the environments in which it occurs.

For Lin (2012) the LA focuses on using accumulated learning data through analysis related techniques to provide appropriate information to learners and facilitating learners to adjust their learning strategies (personalization and adaptation) in improving learning effectiveness. Through learning analytics, activities of teaching, learning, and management processes will be significantly changed. Although learning analytics has been considered one of the six critical trends (ebook, mobile learning, augmented reality, game-based learning, natural user interface, and learning analytics) of high education in the near future, there are only few studies focusing on exploring learning analytics related issues.

For Aljohani \& Davis (2012) the focus of LA is on the learners and their academic performance, learning process, the main goal of this analysis is to identify the learners who might be struggling academically as early as possible, to allow for implementing some intervention strategies that help such students to succeed.

\section{Conclusion}

The mobile learning is just a part of the evolution of Learning as a whole, during four decades, since the published theory concerning three different forms of learning stated by Coombs and Ahmed (1974).

What is the main benefit of M-Learning for the Apprenticeship? The most substantial benefit from the mobile learning might be a long-lasting acquisition of knowledge, re-transferable by the same way that how such information was acquired as much as those already relevant scholastic activities.

Could M-Learning be helpful for solving problems identified by Technology Education? It is hard to make it, but not impossible. As aforementioned, Fabregat (2012) highlights a negative trend, in a way of how the situation should be taken more seriously to correct preliminary results of implementation.

Would M-Learning increase the level of Technological Literacy among the Society? This question is quite similar to the one exposed by Herrera et al (2008; p. 12): "What skills are needed from alumni to learn through m-learning devices?" Therefore, the answer should be the same for the previous question as follows: "It can be stated that every student requires abilities, capabilities and attitudes such as being self-managed and self-organized, evaluation and selection of information, creativity, communication and collaborative work when studying under a form of learning in motion” (Herrera et al, 2008). 


\section{Acknowledgement}

Support for this study has been provided by the Institute of Education, as a part of the Faculty of Social Sciences and Education at the University of Tartu, in the Republic of Estonia. The views expressed in this report do not necessarily reflect the views of the university, to whom I am grateful for being accepted as student of the $\mathrm{PhD}$ in Educational Science (Carlos Pacheco).

\section{References}

[1] Coombs, P. H. Ahmed, M. (1974). Attacking Rural Poverty; How Non-Formal Education Can Help. John Hopkins University Press - Baltimore, United States. ISBN 0-8018-1600-35.

[2] Dieuzeide, H. (1970). Technologie éducative et développement de l'éducation (Educational Technology and Development of Education), Unité spéciale de l'aie-UNESCO. Paris, France.

[3] Farooq, Schafer, Rosson, and Carrol (2002). M-Education: Bridging the Gap of Mobile and Desktop Computing. IEEE Computer Society Washington, DC, USA pp. 91-94 ISBN: 07695-1706-4.

[4] International Technology Education Association (2007). Standards for Technological Literacy: Content for the Study of Technology. T for All A. Project, 3rd Edition. Reston, Virginia. United States. ISBN: 1-887101-02-0.

[5] Januszewski, A. \& Molenda, M. (2008). Definition. In A. Januszewski \& M. Molenda (Eds.), Educational technology: A definition with commentary (1st. ed.). pp. 195-211. New York, US. Lawrence Earlbaum Associates.

[6] Herrington, J. Herrington, A. Mantei, J. Olney, I. \& Ferry, B. (2009). New technologies, new pedagogies: Mobile learning in higher education 138p. University of Wollongong. ISBN: 978-174128-169-9 (online).

[7] Fabregat-Gesa, R. (2012). Combinando la realidad aumentada con las plataformas de e-elearning adaptativas. Enl@ce 9 (2),69-78 ISSN: 1690-7515 (Versión impresa).

[8] Herrera, J. A., Lozano, F. G. y Ramírez, M. S. (2008). Competencias aplicadas por los alumnos para el uso de dispositivos 'm-Learning'. Revista. Iberoamericana de educación 34 (4), 1-10.
[9] Marcos, L, Taméz, R., Lozano, A. (2009). Aprendizaje móvil y desarrollo de habilidades en foros asincrónicos de comunicación. Grupo Comunicar №33, 93-100 ISSN: 1134-3478 (Versión impresa).

[10] Sharples, Mike, Milrad, Marcelo, Arnedillo-Sánchez, Inmaculada and Vavoula, Giasemi, Mobile Learning: Small devices, Big Issues, in: Technology Enhanced Learning: Principles and Products, Springer, 2008.

[11] Zanela-Zaccol, A., Reinhard, N., Schlemmer, E., and Barbosa, J. (2010). M-Learning in practice: a training experience with it professionals. Journal of Information Systems and Technology Management 7 (2), 261-280.

[12] Zapata-Ros, M. (2012). Calidad en entornos ubicuos de aprendizaje. Revista de Educación a Distancia (31), 1-12 ISSN 1578-7680.

[13] Aljohani, Naif R. and Davis, Hugh C. (2012). Learning analytics in mobile and ubiquitous learning environments. In, 11th World Conference on Mobile and Contextual Learning: mLearn 2012, Helsinki, Finland, 16 - 18 Oct 2012.

[14] Alrasheedi, M. \& Capretz, L.F. (2013). Can Mobile Learning Maturity Be Measured? (Preliminary). Proceedings of the Canadian Engineering Education Association Conference - École Polytechnique de Montréal. Quebec, Canada. June 2013 (pp. 1-6)

[15] Berrett, J. (2001). Technological Literacy: Researching Teaching and Learning in the K-12 Setting. Project 2061 - Proceedings of the 2nd American Association for Advancement of S. Technology Education Research Conference

[16] Herrington, A., Herrington, J. \& Mantei, J. (2009). Design principles for mobile learning. In J. Herrington, A. Herrington, J. Mantei, I. Olney, \& B. Ferry (Eds.), New technologies, new pedagogies: Mobile learning in higher education (pp. 129-138)

[17] Kervin, L., \& Mantei, J. (2009). Collaborative gathering, evaluating and communicating 'wisdom' using iPods. In J. Herrington, A. Herrington, J. Mantei, I. Olney, \& B. Ferry (Eds.), New technologies, new pedagogies: Mobile learning in higher education (pp. 99-109).

[18] Lefoe, et al (2009). Faculty development for new technologies: Putting mobile learning in the hands of the teachers. In $\mathrm{J}$. Herrington, A. Herrington, J. Mantei, I. Olney, \& B. Ferry (Eds.), New technologies, new pedagogies: Mobile learning in higher education. Wollongong, Australia (pp. 15-27).

[19] Lin, Hsiu-Fen. Design and implementation of a mobile application for personal learning analytics. Degree: Master, Information Management, 2012, NSYSU. 